\title{
Synonymic notes on North and Central American Lerodea Scudder and Corticea Evans (Lepidoptera, Hesperiidae, Hesperiinae) ${ }^{1}$
}

\author{
Andrew D. Warren ${ }^{2} \&$ Olaf H. H. Mielke ${ }^{3}$ \\ ${ }^{1}$ Contribution number 1498 of the Departamento de Zoologia, Universidade Federal do Paraná. \\ ${ }^{2}$ Department of Zoology, Oregon State University. Corvallis, Oregon, 97331, USA. E-mail: hesperioidea@yahoo.com \\ ${ }^{3}$ Departamento de Zoologia, Setor de Ciências Biológicas, Universidade Federal do Paraná. Caixa Postal 19020, 81531-980 \\ Curitiba, Paraná, Brasil. CNPq Fellowship. E-mail: omhesp@ufpr.br
}

\begin{abstract}
Lerodea dysaules Godman, 1900 is confirmed as a synonym of Lerodea arabus (W. H. Edwards, 1882). A lectotype for Lerodea dysaules is designated. Corticea similea (Bell,1942), comb. nov. is removed from Lerodea Scudder, 1872.

KEY WORDS. Arizona, Texas, Mexico, Neotropical, variation.
\end{abstract}

RESUMO. Notas sinonímicas sobre Lerodea Scudder and Corticea Evans das Américas do Norte e Central (Lepidoptera, Hesperiidae, Hesperiinae). Lerodea dysaules Godman, 1900 é confirmada como sinônimo de Lerodea arabus (W. H. Edwards, 1882). Um lectótipo para Lerodea dysaules é designado. Corticea similea (Bell, 1942), comb. nov. é removida de Lerodea Scudder, 1872.

PALAVRAS CHAVE. Arizona, Texas, México, neotropical, variação.

Following the examination of type specimens in various museums, and extensive fieldwork in many parts of Mexico, Central and South America, several recent changes have been made in the synonymy of Nearctic and Neotropical Hesperiidae (Austin \& Warren 2002, Mielke \& Casagrande 2002, Mielke \& Warren 2004, W ARREN \& MielKe 2004). This note concerns the synonymy and generic placement of some North and Central American species placed by Evans (1955) in the genus Lerodea Scudder.

Lerodea arabus (W. H. Edwards, 1882)

Figs 1-6

Pamphila arabus W. H. Edwards, 1882. Papilio 2: 26, 29, 1 female [holotype], X-1881, S. Arizona, USA, J. Doll leg.

Lerodea dysaules Godman, 1900, in Godman \& Salvin. Biol. Centr.Amer., Lep. Rhop. 2, p. 500; 3, pl. 95, figs 19, 20 (male d, v); 1 male, 1 female, Venta de Zopilote, Guerrero, Mexico, H.H. Smith leg.; collection Godman \& Salvin; lectotype here designated (see: "Material examined"); confirmed synonymy. - MacNeill, 1962. Proc. Calif. Ac. Sc. 30: 11; syn.: arabus. - Tilden, 1964. Jour. Lep. Soc. 18: 214. - L. Miller, 1970. Ann. Carnegie Mus. 41: 170, 171, 197. - MacNeill, 1975, in Howe. Butt. N. Amer., p. 434, pl. 84, fig. 2 (female d, v). - L. Miller \& F.M. Brown, 1981. Mem. Lep. Soc. 2: 50. Ferris, 1989. Mem. Lep. Soc. 3: 74. - Bridges, 1983. Lep. Hesp. 1, p. 37; 2, p. 19. - Bridges, 1988. Cat. Hesp. 1, p. 59; 2, p. 30. - R. G. de la Maza E. \& J. de la Maza E., 1993. Marip. Chiapas, p. 209. - Stanford \& Opler, 1993. Atlas West. USA Butt., p.
93. - Mielke, 2004, Hesperioidea, p. 70, in Lamas (Ed.). Checklist: Part 4A. Hesperioidea - Papilionoidea, in Heppner (Ed.). Atlas of Neotropical Lepidoptera 5A.

Lerodea arabus; Woodworth, 1900. Bull. Univ. Calif. Agric. Exp. Stat. 1: 40. - Lindsey; Bell \& Williams, 1931. Denis. Univ. Bull., Jour. Sc. Lab. 26: 133, pl. 32, fig. 34 (gen. male); syn.: dysaules. - Rindge, 1948. Proc. Calif. Ac. Sc. 24: 309; syn.: dysaules. - Evans, 1955. Cat. Amer. Hesp. 4, p. 394, pl. 82 (gen. male). - Holland, 1973. Jour. Res. Lep. 11: 151. MacNeill, 1975, in Howe. Butt. N. Amer., p. 433, pl. 84, fig. 1 (male d, v). - Tilden, 1964. Jour. Lep. Soc. 18: 215. - L. Miller \& F.M. Brown, 1981. Mem. Lep. Soc. 2: 50. - Bridges, 1983. Lep. Hesp. 1, p. 9, 122; 2, p. 9. - F.M. Brown \& L. Miller, 1987. Trans. Amer. Ent. Soc. 113: 55, 70, fig. 21 (male d, v), neotype male, 21-III-1959, Sabino Canyon, Santa Catalina Mts., Pima Co., Arizona, USA, 2900 ft., Kilian Roever leg., Carnegie Museum of Natural History. - Bridges, 1988. Cat. Hesp. 1, p. 1; 2, p. 30. - Ferris, 1989. Mem. Lep. Soc. 3: 74. - J. Brown, Real \& Faulkner, 1992. Butt. Baja Calif., p. 47, pl. 2, figs 29, 30 (male d, v); syn.: dysaules. - R. G. de la Maza E. \& J. de la Maza E., 1993. Marip. Chiapas, p. 209. Warren, 2000, in Llorente B.; González S. \& Papavero (Eds). Biodiv., Tax., Biogeogr. Artróp. México, p. 564; syn.: dysaules. - Opler \& Warren, 2002. Butt. N. Amer. 2, p. 13; syn.: dysaules. - Bordelon \& Knudson, 2003. Illustr. Checklist Lep. Lower Rio Grande Valley. 1: Butt., p. 52, pl. 17, figs 9, 10 (d, v), pl. 21, fig. 4 (v). - Mielke, 2004, Hesperioidea, p. 

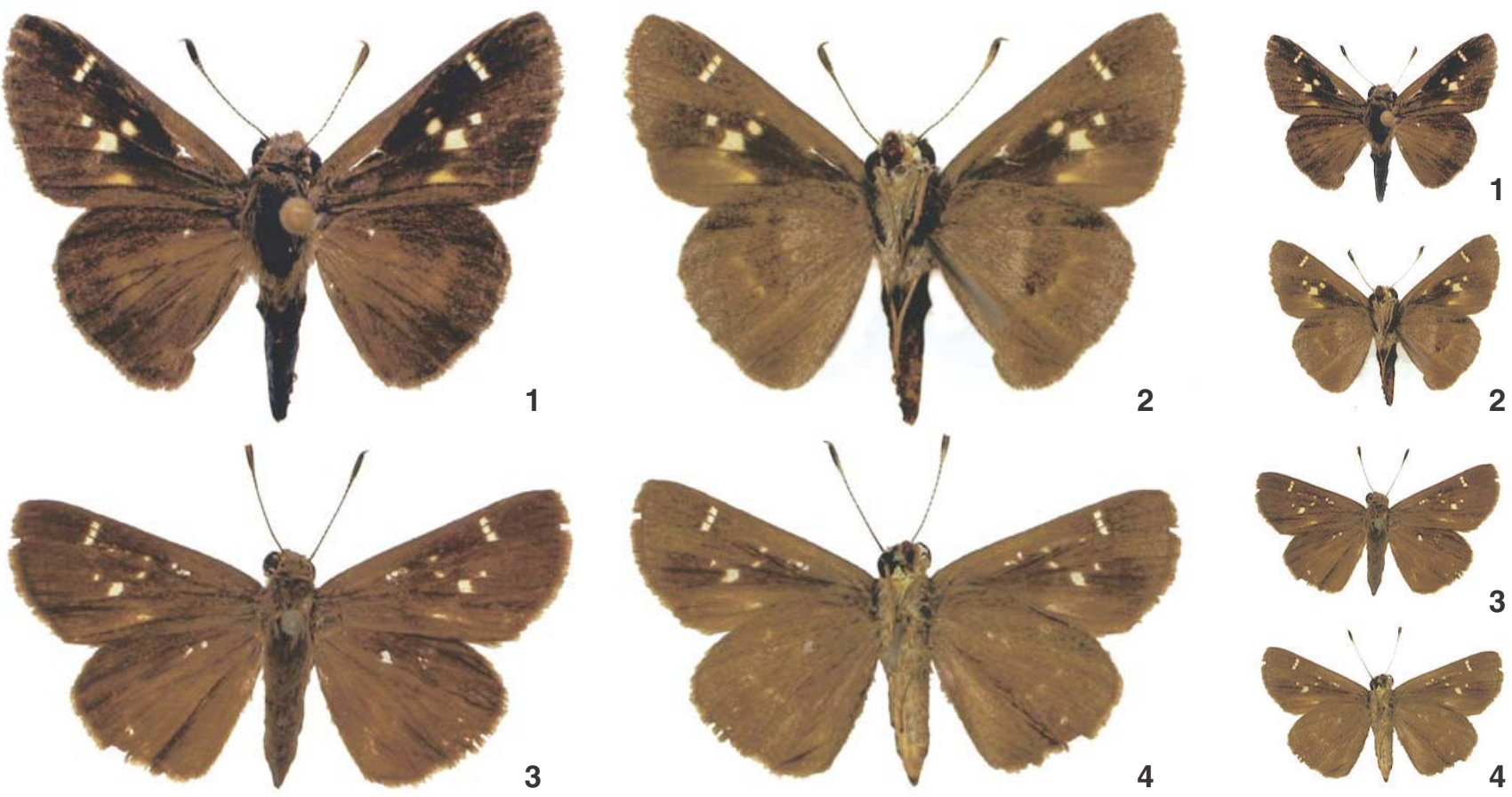

2
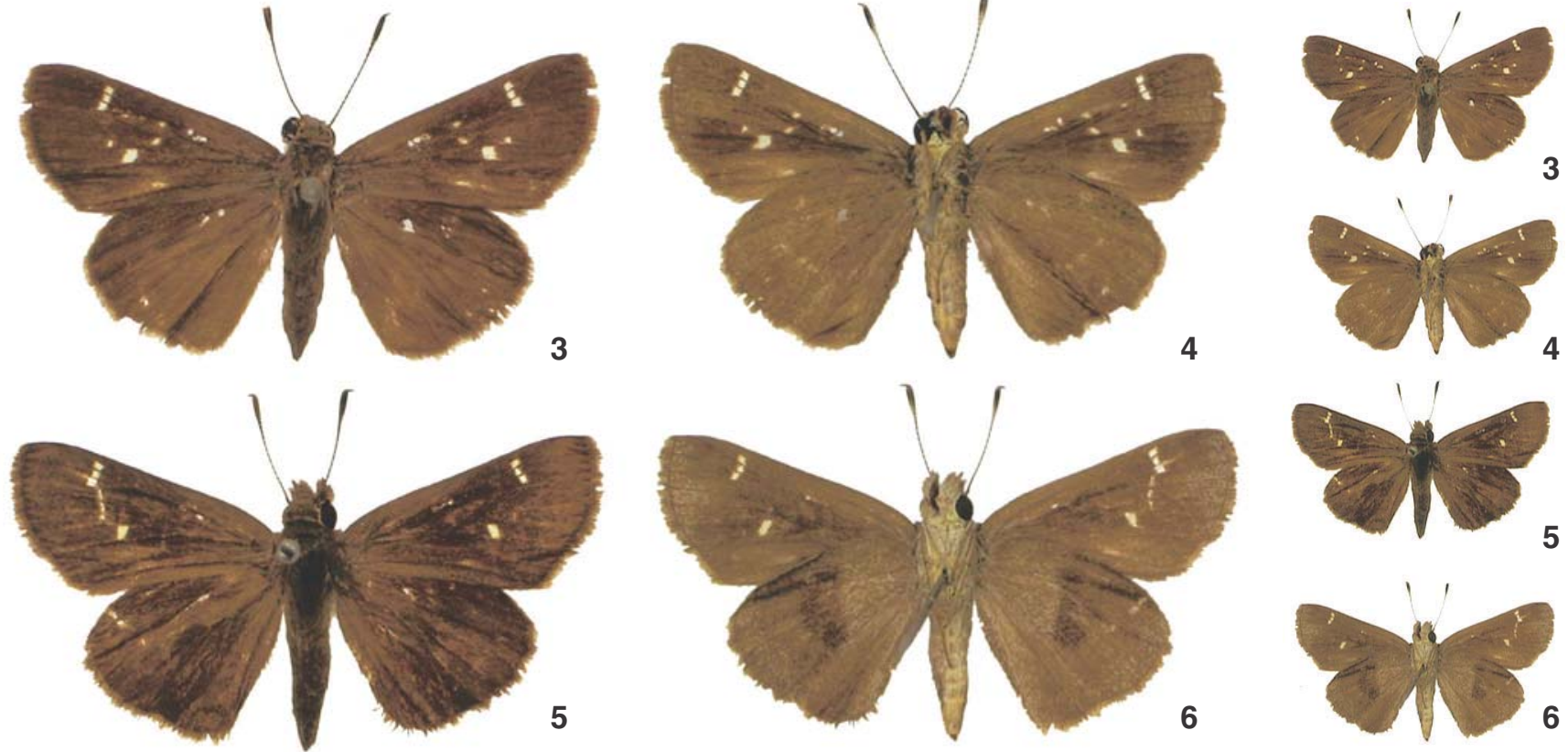

5

Figures 1-6. Lerodea arabus: (1-2) male dorsal, ventral, 2 mi S. Mazatlán, Urias, Mpio. Mazatlán, Sinaloa, Mexico, 29-XII-1992, A.D. Warren leg.; (3-4) female dorsal, ventral, Brownsville, Cameron Co., Texas, USA, 7-VI-1967, H.A. Freeman leg. (5-6) female dorsal, ventral, Brownsville, Cameron Co., Texas, USA, 13-XI-1963, J. W. Tilden leg. Right column natural size.

70, in Lamas (Ed.). Checklist: Part 4A. Hesperioidea Papilionoidea, in Heppner (Ed.). Atlas of Neotropical Lepidoptera $5 \mathrm{~A}$.

Lerodea arabus arabus; Scott, 1986. Butt. N. Amer., p. 465, pl. 46, fig. 556a (male v).

Lerodea arabus dysaules; Scott, 1986. Butt. N. Amer., p. 465, pl. 46 , fig. 55b, c (female d, v).

Godman (1900) described Lerodea dysaules from a pair of specimens, but made no mention of, or comparison with Pamphila arabus W. H. Edwards, 1882. Lindsey et al. (1931) treated L. dysaules as a synonym of Lerodea arabus, however Evans (1955) treated $L$. arabus and $L$. dysaules as distinct species, separating the taxa based on the presence or absence of ventral hindwing discal spots (present in arabus, absent in dysaules), and on the position of the white forewing cell spot. According to Evans, $L$. arabus has a conspicuous spot in the upper half of the forewing cell, while $L$. dysaules lacks this spot but has a similar spot in the lower half of the forewing cell. Evans (1955) examined only 1 male specimen of $L$. arabus from Arizona, USA, and one pair of $L$. dysaules from Guerrero, Mexico (the type material). Despite Evans' total sample size of three specimens, and his disclaimer (1955) that $L$. dysaules may be a subspecies of arabus, his arrangement of L. arabus and L. dysaules as two species has been generally followed (Tilden 1964, MacNeill 1975, L. Miller \& F.M. Brown 1981, Ferris 1989, Mielke 2004). However, MACNeill $(1962,1975)$ and J. Brown et al. (1992) noted significant variability in the characters used to separate the taxa, and Scotr (1986) treated $L$. dysaules as a subspecies of $L$. arabus. More recently, several authors (WARREn 2000, Opler \& WARREN 2002, Bordelon \& KNUdSON 2003) have treated L. dysaules as a 

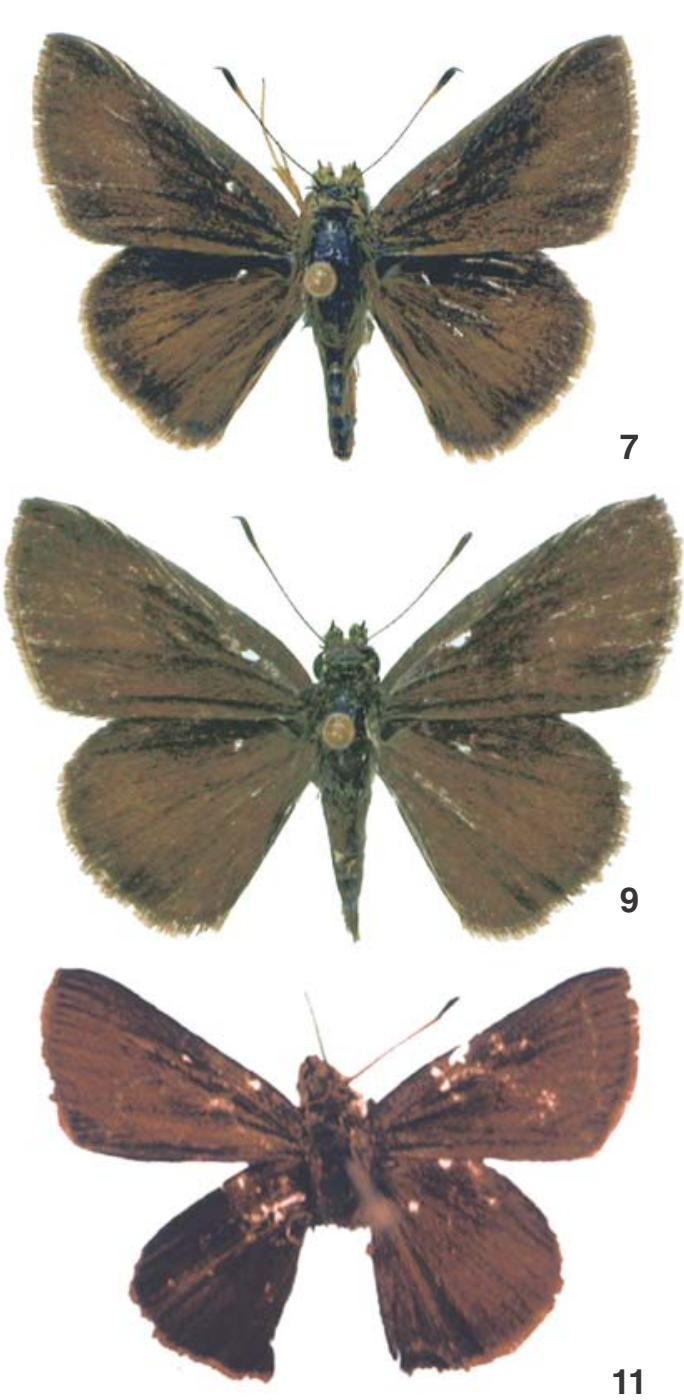

Figures 7-12. Corticea similea: (7-8) male dorsal, ventral, Caracha, 1320 m, Mpio. Ziracuaretiro, Michoacán, Mexico, 14-V-1997, Lamberto González-Cota leg.; (9-10) female dorsal, ventral, Zirimicuaro, ca. 1450 m, Mpio. Ziracuaretiro, Michoacán, Mexico, 15-VI-1996, Lamberto González-Cota leg.; (11-12) holotype male dorsal, ventral, Guerrero, Mexico, VII, R. Müller leg. (AMNH). Right column natural size.

synonym of $L$. arabus, without elaboration. Here the status of these taxa is discussed, and an explanation of why L. dysaules should be treated as a synonym of $L$. arabus is offered.

Neither of the characters used by Evans (1955) to distinguish the two taxa show consistency when large series of specimens are examined. The expression of ventral hindwing discal spots appears to vary individually and seasonally, with individuals in drier months being better maculated. Of two female individuals examined from Brownsville, Cameron Co., Texas, USA, the June (dry season) individual (Figs 3,4) shows well-developed ventral hindwing discal spots as in the neotype of L. arabus (designated by M. Brown \& L. Miller 1987), while the November (rainy season) individual (Figs 5, 6) lacks these spots (as would dysaules), and has a more strongly contrasting ventral hindwing pattern. This pattern of variation is typical for what is seen throughout Mexico, with individuals from transition months (December, January, June, July) showing the greatest phenotypic variation. Consistent patterns of geographic variation in ventral hindwing maculation have not been noticed.

The position of the forewing cell spot has proven to be even less reliable than ventral hindwing maculation in diagnosing the two taxa. For example, the June individual (Figs 3, 4) from Brownsville, Texas, USA, has both upper and lower cell spots, while the November individual (Figs 5, 6) from Brownsville lacks any trace of forewing cell spots. These extremes in variation represent the typical range of variation seen 
at all sites from which series of specimens have been examined, but according to Evans (1955), represent neither taxon. Indeed about $40 \%$ of the Mexican specimens examined have both upper and lower forewing cell spots, which is not typical for either $L$. arabus or $L$. dysaules.

Male genitalia $(n=12)$ of individuals representing all combinations of wing spotting patterns were compared (from Arizona - USA, Sinaloa, Nayarit, Jalisco and Michoacán Mexico), including typical arabus, typical dysaules, and all other variants seen; no differences of any kind could be deciphered between them. The supposed differences between L. arabus and L. dysaules in male genitalia illustrated by Evans (1955) are inaccurate. The actual structure of the valvae of the species is most like Evans' illustration of L. dysaules, while the uncus and gnathos, from lateral view, actually appear intermediate between Evans' illustrations for L. arabus and L. dysaules.

After examining the type material of both taxa, as well as over 80 specimens from throughout the range of both taxa, it is concluded that Lerodea arabus shows much individual and seasonal variation, and that its junior synonym $L$. dysaules represents just one of many forms seen in the species throughout its geographic range.

Material examined (Roman numbers refer to months of capture, Arabic numbers between parenthesis indicate the number of specimens examined): Lectotype of Lerodea dysaules Godman, 1900 here designated: male with the following labels: /Type/ Type H. T./ ${ }^{*} /$ Sp. figured/ Venta de Zopilote, Guerrero, $2800 \mathrm{ft}$. Oct. H. H. Smith/ B. C. A. Lep. Rhop. Lerodea dysaules, Godm./ Godman-Salvin Coll. 1913. -2/ "paper with the genitalia"/; BMNH. Méxıco, Colima: Mpio. Colima III (1); Mpio. Comala IV (1); Guerrero: Mpio. unknown X (3); Jalisco: Mpio. Chapala VII (1), IX (1); Mpio. Puerto Vallarta XII (4); Michoacán: Mpio. Arteaga VI (1), VII (2); Mpio. Gabrie Zamora VIII (1), X (1), XII (1); Mpio. Parácuaro VIII (1); Mpio. Taretan VII (1); Mpio. Uruapan: I (1), II (2), V (1), X (1), XI (2); Nayarit: Mpio. Bahía de Banderas I (1); Oaxaca: Mpio. San Pedro Totolapan VIII (2); Puebla: Mpio. Acatlán de Osorio VIII (1); San Luis Potosí: Mpio. Valles VI (2), VII (1), VIII (1); Sinaloa: Mpio. Mazatlán I (5), IV (1), X (1), XI (10), XII (11); SONORA: Mpio. Hermosillo X (1); Mpio. Yecora III (2); Tabasco: Mpio. Tepescuintle IX (3); Tamaulipas: Mpio. Victoria I (1), XII (4). USA: ARIZONA: no locality (2); Santa Cruz Co., VII (5); TEXAS: Cameron Co., VI (1), XI (1).

Literature records of this species from the following Mexican states include, in addition to those listed above: Baja California Sur (Rindge 1948 [as L. arabus], MacNeill 1962 [as L. dysaules], L. Miller 1970 [as L. dysaules], Holland 1973 [as L. arabus], MacNeill 1975 [as L. arabus], J. Brown et al. 1992 [as L. arabus]), Campeche (Pozo et al. 2003 [as L. arabus]), Chiapas (de la MAzA \& de la MazA, 1993 [as L. arabus and L. dysaules]), Durango, Nuevo León (STANFord \& Opler 1993 [as L. dysaules]), and Veracruz (unpublished). Lerodea arabus has not been recorded from Guatemala (Austin et al. 1998).

\section{Corticea similea (Bell, 1942), comb. nov. Figs 7-21}

Lerodea similea Bell, 1942. An. Esc. Nac. Ciencias Biol., Mexico, 2: 466, fig. 9 (gen. male); holotype male, July, Guerrero, Mexico, R. Müller leg., no. 14.098; Escuela Nacional de Ciencias Biológicas, Mexico [AMNH]. - Evans, 1955. Cat. Amer. Hesp. 4, p. 396. - Okano, 1981. Tokurana 1: 60. - Bridges, 1983. Lep. Hesp. 1, p. 109; 2, p. 19. - Bridges, 1988. Cat. Hesp. 1, p. 173; 2, p. 31. - Llorente-Bousquets; Luis-Martínez \& VargasFernández, 1990. Publ. esp. Mus. Zool., Mexico, 1: 42. - J. de la Maza E.; White \& R. G. de la Maza E., 1991. Rev. Soc. Mex. Lep. 14: 41. - Warren, 2000, in Llorente B.; González S. \& Papavero (Eds). Biod., Tax., Biogeogr. Art. Mex. 2, p. 543, 564. - Mielke, 2004, Hesperioidea, p. 70, in Lamas (Ed.). Checklist: Part 4A. Hesperioidea - Papilionoidea, in Heppner (Ed.). Atlas of Neotropical Lepidoptera $5 \mathrm{~A}$.

The male holotype (Figs 11, 12), examined by the authors on two separate occasions at the American Museum of Natural History (AMNH), is from the Roberto Müller collection. In its original description, BeLL noted the superficial similarity of L. similea to L. noctis (Plötz, 1883), a species currently placed in Corticea (Mielke 1969). Evans (1955) listed L. similea as one of 13 species unknown to him (and not identified in the BMNH collection) that were described in Lerodea. Clearly, Evans did not know the identity of $L$. similea when he described the genus Corticea. Unknown to all subsequent authors (Llorente-Bousquets et al. 1990, J. de la Maza E. et al. 1991, LuisMartínez et al. 2003, Mielke, 2004), L. similea has remained in Lerodea Scudder, 1872 until now.

Upon examining the holotype male of L. similea (Figs $11,12)$, the authors were immediately impressed by the unmistakable superficial similarity of $L$. similea to various Corticea Evans, 1955 species, as noted by BeLL (1942). The male genitalia of similea, as illustrated by BELL (1942), are unlike most other described Corticea species only in that the distal tips of the valvae are not elongated, although valvae of some specimens of C. lysias potex Evans, 1955 (see Mielke 1969) approach the rounded shape seen in C. similea. The genitalia of one male $C$. similea from Michoacán (Figs 13-19) were dissected and compared to the genitalia of the holotype of $L$. similea, and with that of other Corticea species in the laboratory and in the literature (Mielke 1969). Details of the uncus, gnathos, saccus, aedeagus, and even valvae (except their distal tips) of $C$. similea, when viewed from all angles, are very consistent with other described species of Corticea, leaving no doubt that $L$. similea shares a very close relationship with other Corticea species. Female genitalia of L. similea (Figs 20-21) are illustrated herein for the first time.

Due to very significant external and genitalic similarities between similea and other Corticea species, it is concluded that similea belongs in Corticea (sensu Mielкe 1969). To date, Corticea similea is known only from the southwestern Mexican 


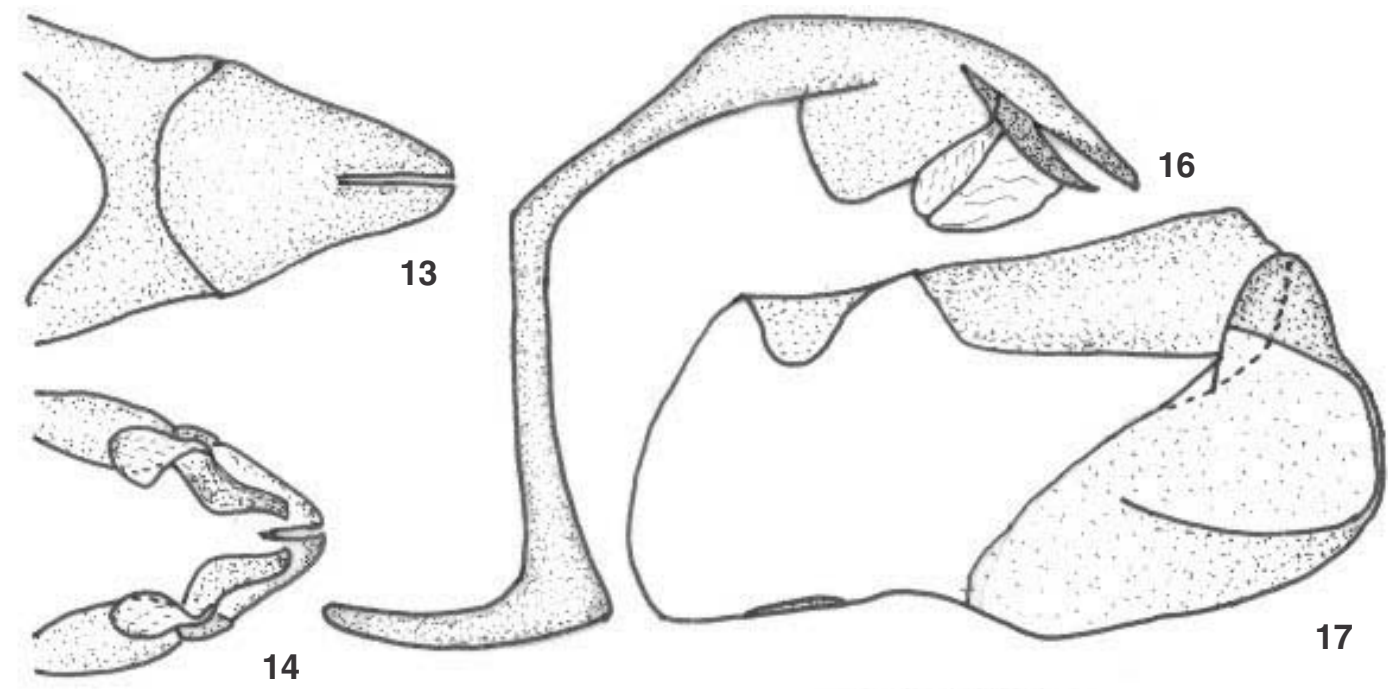

14
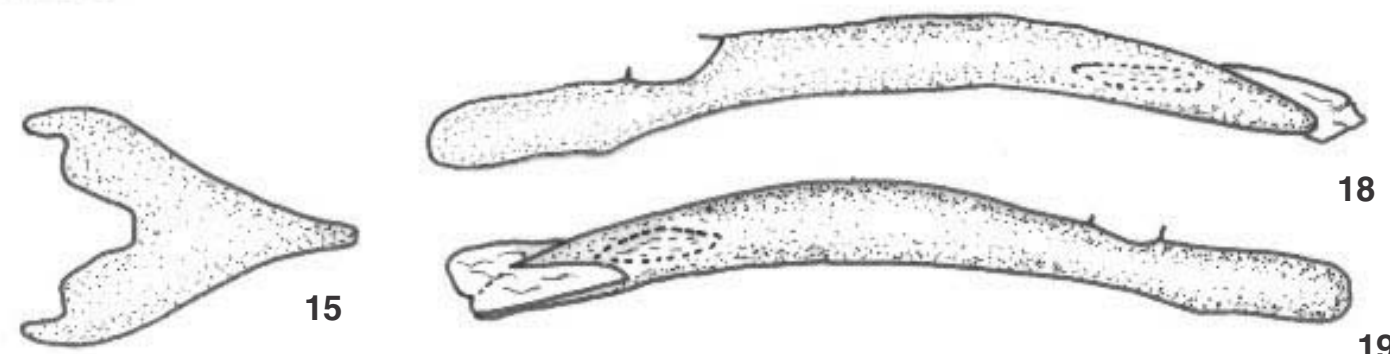

19
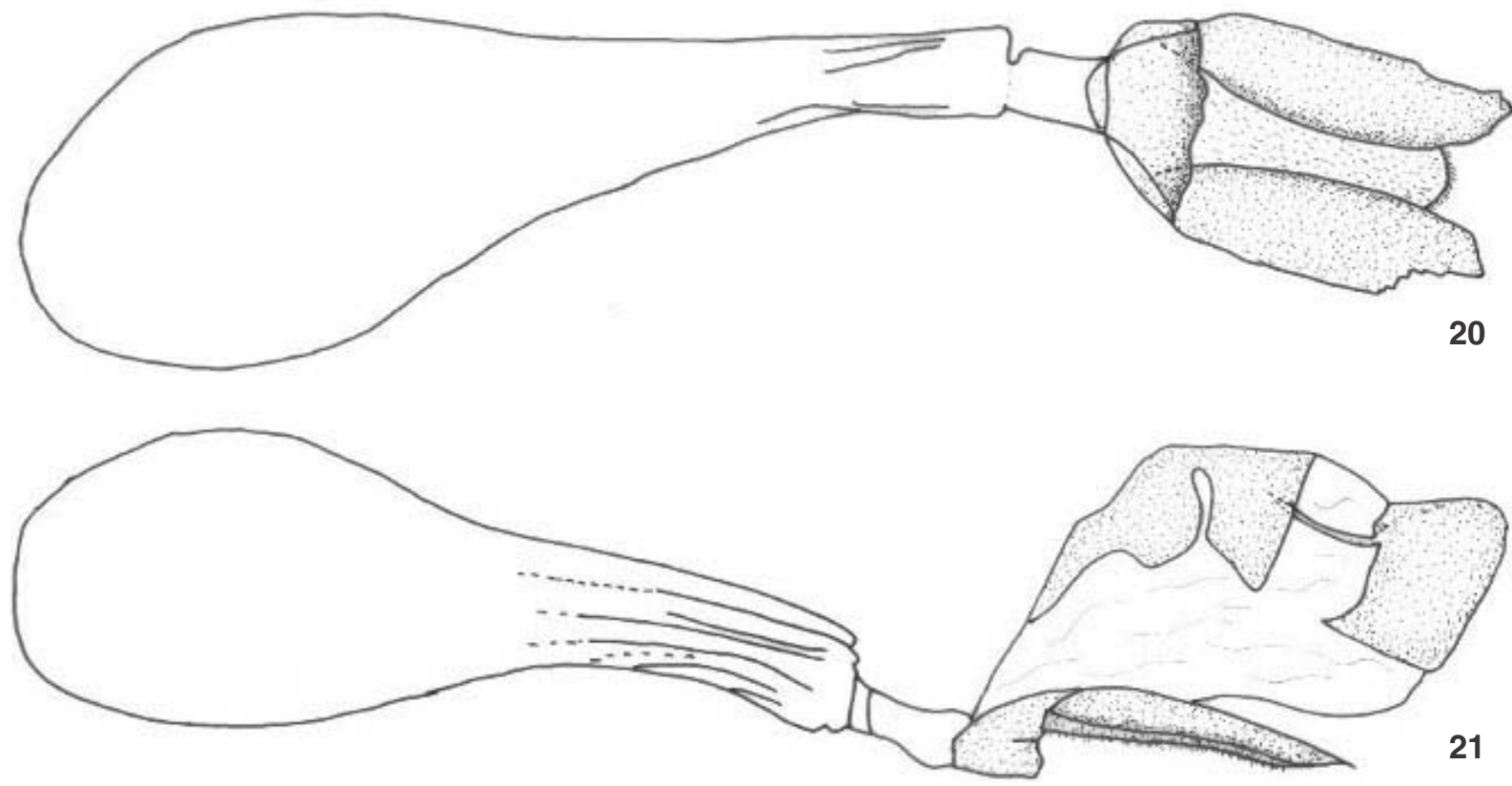

Figures 13-21. (13-19) Corticea similea, male genitalia, from Santa Rosa, Mpio. Uruapan, Michoacán, Mexico, 31-VIII-1990, 1640 m, Lamberto González-Cota leg.: (13) dorsal view of tegumen and uncus; (14) ventral view of gnathos and uncus; (15) ventral view of juxta; (16) lateral view of tegumen, saccus, uncus and gnathos; (17) internal view of right valva; (18) left lateral view of edeagus; (19) right lateral view of edeagus; (20-21) Corticea similea, female genitalia, from Santa Rosa, Mpio. Uruapan, Michoacán, Mexico, 13-VIII1991, 1640 m, Lamberto González-Cota leg.: (22) ventral view; (23) left lateral view. 
states of Guerrero and Michoacán, and appears to be endemic to Mexico (Luis-Martínez et al. 2003). A recently collected male (Figs 7-8) and female (Figs 9-10) are illustrated herein.

Material examined (includes all known specimens): Mexico: Guerrero: (no locality) VII, R. Müller colln. n114.098, 1 male, holotype, AMNH; same locality, VIII, R. Müller colln. n114.152, 1 female, AMNH; Michoacán: Mpio. Uruapan: Santa Rosa, 1640 m, 31-VIII-1990, 13-VIII-1991, L. González-Cota leg., 1 male, 1 female; Mpio. Ziracuaretiro: Caracha, 1320 m, 14-V1997, L. González-Cota leg., 1 male; same locality, 27-VIII-1997, Andrew D. Warren leg., 1 male; Zirimicuaro, ca. 1450 m, 15-VI1996, 6-VII-1996, 1 female, 1 male, L. González-Cota leg.

\section{ACKNOWLEDGMENTS}

The senior author thanks the Pew Undergraduate Research Fellowship at Cornell University (Ithaca, New York) for providing funds to study at the AMNH in 1995, and the United States National Science Foundation (Doctoral Dissertation Improvement Grant), which provided funds to travel to Brazil in February and March of 2004. He also thanks Jorge LlorenteBousquets, Armando Luis-Martínez and Isabel Vargas-Fernández (Museo de Zoología, UNAM, Mexico City) for arranging collecting permits and enabling the study of material cited herein, and Lamberto González-Cota (Uruapan, Michoacán) for his hospitality during August, 1997. We would also like to thank the late H. A. Freeman for sharing specimens and information related to this paper, and to Gerardo Lamas, Museo de Historia Natural, Lima, Peru, and an anonymous reviewer for reviewing this paper and providing valuable suggestions. The junior author thanks CNPq (Conselho Nacional de Desenvolvimento Científico e Tecnológico) for providing a research fellowship.

\section{REFERENCES}

Austin, G.T.; C. Méndez \& A.E. Launer. 1998. A preliminary checklist of Guatemala butterflies: Hesperiidae (Lepidoptera: Hesperioidea). Tropical Lepidoptera, Gainesville, 9 (Suppl. 2): 8-18.

Austin, G.T. \& A.D. Warren. 2002. Taxonomic notes on some Neotropical skippers (Lepidoptera: Hesperiidae): Pyrrhopyginae and Pyrginae. Dugesiana, Guadalajara, 9 (2): 15-49.

BELL, E.L. 1942. New records and new species of Hesperiidae from Mexico (Lepidoptera: Hesperiidae). Anales de la Escuela Nacional de Ciencias Biológicas, Mexico, 2 (4): 455-468.

Bordelon, C. \& E. Knudson. 2003. Illustrated Checklist of Lepidoptera of the Lower Rio Grande Valley. Part 1: Butterflies. TLS PUB. 9a. Houston, Texas Lepidoptera Survey, XVIII+54p.

BRIDGES, C.A. 1983. Lepidoptera: Hesperiidae. notes on speciesgroup names. II. Urbana, Ed. Charles A. Bridges, Part 1, 129p.; Part II, 41p.; Part III, 62p.; Part IV, 30p.; Part V, 13p.

BRIDGes, C.A. 1988. Catalogue of Hesperiidae (Lepidoptera: Rhopalocera). VII. Urbana, Ed. Charles A. Bridges, Part 1, 205p.; Part II, 67p.; Part III, 78p.; Part IV, 54p.; Part V, 20p.; Part 6, 7p.; Appendix I. Synonymic List of FamilyGroup Names, 1 p.; Appendix II. Synonymic List of Genus-Group Names, 8p.; Annotations on the Catalogue of Hesperiidae, $6 \mathrm{p}$.

Brown, F.M. \& L.D. Miller. 1987. The types of the Hesperiid butterflies described by William Henry Edwards. Part III Hesperiidae: Hesperiinae, section III and Megathymidae. Transactions of the American Entomological Society, Philadelphia, 113: 29-71.

Brown, J.W.; H.G. Real \& D.K. FaulKner. 1992. Butterflies of Baja California. Faunal Survey, Natural History, Conservation Biology. Beverly Hills, The Lepidoptera Research Foundation, IV+129p.

Evans, W.H. 1955. A Catalogue of the American Hesperiidae indicating the classification and nomenclature adopted in the British Museum (Natural History). Part IV. Hesperiinae and Megathyminae. London, British Museum, $\mathrm{V}+499 \mathrm{p}$.

FerRIs, C.D. 1989. Supplement to: A Catalogue/Checklist of the Butterflies of America North of Mexico. Memoirs of the Lepidopterists' Society, Los Angeles, 3: I-VIII, 1-103.

Godman, F.D. \& O. Salvin. 1879-1901. Biologia Centrali-Americana. Insecta, Lepidoptera Rhopalocera. London, Dulau \& Co., Bernard Quaritch, vol. II, 782 p., vol. III, 112 pl.

Holland, R. 1973. Butterflies of middle and southern Baja California. Journal of Research on the Lepidoptera, Arcadia, 11 (3): 147-160.

Lindsey, A.W.; E.L. Bell \& R.C. Williams Jr. 1931. The Hesperioidea of North America. Denison University Bulletin. Journal of the Scientific Laboratories, Granville, 26 (1): 1-142.

Llorente-Bousquets, J.E.; A. Luis-Martínez \& I. Vargas-Fernández. 1990. Catalogo sistemático de los Hesperioidea de México. Publicaciones Especiales del Museo de Zoología, México, 1: [I-IV], 1-70.

Luis-Martínez, A.; J.E. Llorente-Bousquets; I. Vargas Fernández \& A.D. Warren. 2003. Biodiversity and biogeography of Mexican butterflies (Lepidoptera: Papilionoidea and Hesperioidea). Proceedings of the Entomological Society of Washington, Washington, 105 (1): 209-224.

MaCNEILL, C.D. 1962. A preliminary report on the Hesperiidae of Baja California (Lepidoptera). Proceedings of the California Academy of Sciences, San Francisco, 30 (5): 91-116.

MacNeill, C.D. 1975. Hesperiidae, p. 423-578. In W.H. Howe (Ed.). The Butterflies of North America. New York, Doubleday and Co., 633p.

Maza E., R.G. de la \& J. de la Maza E. 1993. Mariposas de Chiapas. México, Gobierno del Estado de Chiapas, 223p.

Maza E., J. de la; A.L. White \& R.G. DE la Maza E. 1991. La fauna de mariposas de México. Part II. Hesperioidea (Lepidoptera: Rhopalocera). Revista de la Sociedad Mexicana de Lepidopterologia, Mexico, 14 (1): 3-44.

Revista Brasileira de Zoologia 22 (1): 285-291, março 2005 
MielKe, O.H.H. 1969. Notas sôbre as espécies do gênero Corticea, com descrição de três espécies novas (Lepidoptera: Hesperiidae). Boletim da Universidade Federal do Paraná, Zoologia, Curitiba, 3 (6): 143-166.

MielKe, O.H.H. 2004. Hesperioidea, p. 3-11, 25-86. In: G. LAMAS (Ed.). Checklist: Part 4A. Hesperioidea - Papilionoidea. In: J.B. Heppner (Ed.). Atlas of Neotropical Lepidoptera 5A. Gainesville, Scientific Publishers, XXXVI+439p.

Mielke, O.H.H. \& M.M. Casagrande. 2002. Notas taxonômicas em Hesperiidae neotropicais, com descrições de novos taxa (Lepidoptera). Revista Brasilera de Zoologia, Curitiba, 19 (Supl. 1): 27-76.

MielKe, O.H.H. \& A.D. Warren. 2004. The identity of Eudamus valeriana Plötz, 1881 (Lepidoptera, Hesperiidae, Pyrginae). Revista Brasileira de Zoologia, Curitiba, 21 (2): 307-308.

Miller, L.D. 1970. Reports on the Margaret M. Cary-Carnegie Museum expedition to Baja California, Mexico, 1961. 7. The family Hesperiidae (Lepidoptera). Annals of Carnegie Museum, Pittburgh, 41 (5): 169-200.

Miller, L.D. \& F.M. Brown. 1981. A Catalogue/Checklist of the Butterflies of America North of Mexico. Memoirs of the Lepidopterists' Society, Sarasota, 2: I-VII, 1-280.

Opler, P.A. \& A.D. WARren. 2002. Butterflies of North America. 2. Scientific names list for butterfly species of North America, North of Mexico. Fort Collins, Contributions of the C.P. Gillette Museum of Arthropod Diversity, Colorado State University, 79p.
Pozo, C.; A.M. Luis; S.T. UC; N.S. Salas \& A.M. MaYa. 2003. Butterflies (Papilionoidea \& Hesperioidea) of Calakmul, Campeche, México. The Southwestern Naturalist, Hays, Kansas, 48 (4): 505-525.

RindGe, F.H. 1948. Contributions toward a knowledge of the insect fauna of lower California. No. 8. Lepidoptera: Rhopalocera. Proceedings of the California Academy of Sciences, San Francisco, (4) 24 (8): 289-312.

ScotT, J.A. 1986. The Butterflies of North America. A Natural History and Field Guide. Stanford, Stanford University Press, 583p.

StANFORD, R.E. \& P.A. Opler. 1993. Atlas of Western USA Butterflies, Including Adjacent Parts of Canada and Mexico. Fort Collins, Published by authors, $\mathrm{X}+275 \mathrm{p}$.

Tilden, J.W. 1964. Two species of Hesperiidae previously unrecorded from the United States. Journal of the Lepidopterists' Society, New Haven, 18 (4): 214-216.

WARREN, A.D. 2000. Hesperioidea (Lepidoptera), p. 535-580. In: J.E. Llorente Bousquets; E. González Soriano \& N. Papavero (Eds). Biodiversidad, taxonomía y biogeografía de artrópodos de México: hacia una síntesis de su conocimiento. México, Universidad Nacional Autónoma de México, vol. 2, XVI+676p.

Warren, A.D. \& O.H.H. Mielke. 2004. Mysoria affinis (HerrichSchäffer): morphological variation and synonymy (Lepidoptera, Hesperiidae, Pyrrhopyginae). Revista Brasileira de Zoologia, Curitiba, 21 (2): 309-314.

Received in 17.VI.2004; accepted in 08.III.2005. 